\title{
a trajetória da perfumarias phebo em belém ${ }^{\star}$
}

\section{the trajectory of perfumarias phebo in belém}

\author{
Marcílio Alves Chiacchio $\star \star$ \\ Universidade Estadual de Roraima, Boa Vista, Roraima, Brasil
}

\begin{abstract}
Resumo
O atual trabalho é um estudo sobre história de empresa, tendo como estudo de caso a Perfumarias Phebo, uma empresa paraense fundada por portugueses, que se destacou no mercado de perfumaria brasileiro. $\mathrm{O}$ método de pesquisa consistiu no levantamento de informações arquivistas, trajetória histórica e evolução administrativo-financeira no período de 1936 a 1988, pesquisa esta realizada a partir de informações disponibilizadas pela empresa, entrevistas e coleta de material. A empresa utilizou o pau-rosa (Aniba rosaeodora Ducke), uma matéria-prima oriunda da Amazônia, para criar o seu produto de maior aceitação no mercado, o sabonete Phebo Odor de Rosas. A perfumaria tornou-se líder no mercado de perfumaria nacional, instalando fábricas nas cidades de São Paulo (SP) e Feira de Santana (BA). Em 1988 a empresa foi vendida para o grupo Procter \& Gamble Company.
\end{abstract}

Palavras-chave: Phebo. Pau-rosa (Aniba rosaeodora Ducke). Amazônia. Portugueses.

\begin{abstract}
Aвtratct
The current work is a case study which researched the history of the Phebo Perfumeries. Phebo was a company from the state of Pará, Brazil, founded by Portuguese, that stood out in the Brazilian perfumery market. The research method consisted in the collection of archival information, historical trajectory and administrative and financial evolution from 1936 to 1988, based on information provided by the company, interviews and material collection. The company used the rosewood (Aniba rosaeodora Ducke), a raw material from the Amazon, to create its most widely accepted product in the market: Phebo Odor de Rosas soap. Phebo became a leader in the national perfumery market, opening factories in the cities of São Paulo (state of São Paulo) and Feira de Santana (state of Bahia). In 1988 the company was sold to the Procter \& Gamble Company group.
\end{abstract}

Keywords: Phebo. Pau-rosa (Aniba rosaeodora Ducke). Amazon. Portuguese.

* Agradecimentos à Coordenação de Aperfeiçoamento de Pessoa de Nível Superior pela bolsa de mestrado que possibilitou a dedicação exclusiva ao trabalho de pesquisa. Um artigo avaliando as empresas Fábrica Palmeira, Fábrica Perseverança e Perfumarias Phebo foi apresentado no XII CONGRESSO DE HISTÓRIA ECONÔMICA e na 13a CONFERÊNCIA INTERNACIONAL DE HISTÓRIA DE EMPRESAS NA CIDADE DE NITERÓI - RJ, em 2017.

Submetido: 19 de fevereiro de 2018; aceito: 10 de março de 2019.

$\star \star$ Professor da Universidade Estadual de Roraima, doutorando em Economia pela Universidade Federal do Pará e mestre em Planejamento do Desenvolvimento. E-mail: marcilio.ac@gmail.com 


\section{Introdução}

No início do século XX, a cidade de Belém vivia o ápice do período da borracha. O que possibilitou o surgimento de vários empreendimentos industriais, aproveitando o chamado "boom da borracha" (Benchimol, 1966; Santos, 1980; Baer, 1983). Nessa época de grande prosperidade, por volta de 1924, nascia, na cidade de Belém do Pará, a empresa A. L. Silva Companhia Limitada. Era uma perfumaria que possuía uma gama de produtos para higiene e limpeza. Entre os seus principais destaques, estava o conhecido sabonete Phebo Odor de Rosas, que era oval, transparente e escuro e tornou-se uma referência em vendas no Brasil e no mundo.

No começo das suas atividades, a grande dificuldade da empresa foi com a logística e a distribuição dos seus produtos. A capital paraense, localizada na região amazônica, possuía poucas alternativas de transportes no início do século XX, e a mais utilizada era a via marítima. Os produtos demoravam para chegar ao seu destino, por conta disso, muitas vezes eram vendidos em forma de consignação (Phebo, 1988).

Com os avanços dos negócios, a empresa expandiu-se, criando uma filial em São Paulo, em 1961, e outra em Feira de Santana, em 1973. Durante a sua história, a Phebo se manteve entre as principais empresas do setor de perfumaria do país. Era uma empresa familiar, que tinha como maior líder Mário Santiago, que veio a falecer no mesmo dia em que a empresa foi vendida. Em 19 de abril de 1988, o controle acionário da empresa passou para a Procter \& Gamble Company, grande multinacional americana. E por fim, no dia 23 de setembro de 1988, a empresa transferiu todo controle administrativo para a multinacional.

O objetivo deste trabalho é analisar a dinâmica da Perfumarias Phebo S/A no período de 1936 a 1988 e sua contribuição para o desenvolvimento local da mesorregião metropolitana de Belém. Nessa direção, o trabalho tem como ponto central a reconstituição histórica da Perfumarias Phebo, ou seja, trata-se de um trabalho de história econômica, tendo como campo de atuação a história de empresas. A problemática de pesquisa foi: "Como se deu a trajetória da Perfumarias Phebo e quais suas contribuições para a indústria de Belém e do Brasil?”.

A pesquisa foi construída a partir de procedimentos que envolveram pesquisa bibliográfica, pesquisa documental, entrevistas e pesquisa de 
campo (Günther, 2006; Kuhn, 2006;Yin, 2001). Utilizou-se de teóricos que analisaram a teoria da firma, principalmente de autores como Schumpeter (1982) e Penrose (2006). Sua operacionalidade metodológica se deu a partir do método hipotético-dedutivo, no qual Bunge (1974a, p. 70-72, apud Lakatos; Marconi, 1985, p. 95) afirma que é possível uma "classificação preliminar e seleção dos fatos", "redução do problema a um núcleo significativo".

As principais fontes de dados primários foram balanços e notícias conseguidos em jornais de época, resultados financeiros publicados na Revista Exame e na Gazeta Mercantil, atas de reuniões, cartas, panfletos de propaganda, embalagens e entrevista com antigos diretores. No primeiro momento, buscaram-se informações na sede da empresa em Belém (hoje pertencente à Casa Granado). Lá se conseguiram atas de reuniões de vendedores, comunicados internos, cartas, reportagens jornalísticas e de revistas internas, e principalmente se obteve uma entrevista com o atual gerente da empresa. Mesmo assim, eram poucos os materiais, uma vez que, ao se desfazer da fábrica em Belém, a Procter \& Gamble levou consigo todos os arquivos que existiam na empresa.

Perante essa grande dificuldade, a alternativa foi buscar informações fora da empresa. Dalla Costa (2004) aponta a dificuldade em conseguir informações e arquivos sobre empresas, e também a veracidade das informações contidas em revistas de circulação.Assim, para se conseguirem balanços e reportagens sobre a firma, utilizou-se da Biblioteca do Centro Cultural Tancredo Neves (CENTUR), localizado no Bairro da Cremação em Belém. Na biblioteca, recorreu-se a notícias de jornais antigos, tais como A Província do Pará, Folha do Norte, Diário do Estado do Pará, Revista Comercial do Pará, Diário do Pará e O Liberal. Enfim, foram esquadrinhados jornais e revistas datados de 1932 a 1988. Além das revistas da década de 1970 e 1980, como a Revista Exame, Maiores e Melhores e a Gazeta Mercantil, consultadas na Universidade de São Paulo (USP). Na Junta Comercial do Estado do Pará (JUCEPA), foi possível encontrar antigas certidões da empresa contendo informações sobre a sua fundação, os seus sócios e a evolução da empresa de "limitada" para "sociedade anônima".

No que diz respeito às entrevistas, buscou-se contatos com os antigos diretores da empresa e o atual administrador, Roberto Lima. Para encontrar os antigos diretores, teve-se que recorrer à lista telefônica, 
porque a família Santiago, depois da venda, não mais retornou à empresa. Assim, foram encontrados os contatos de Ramiro Santiago e Sônia Santiago, ex-diretor industrial e ex-vice-presidenta da empresa, respectivamente. Com as entrevistas foi possível obter informações quanto ao funcionamento administrativo da empresa e os seus principais acontecimentos.

Portanto, o objetivo do trabalho é estudar a história empresarial da Phebo no período 1936-1988, mediante os dados levantados sobre a trajetória da empresa que procuram demonstrar a capacidade empresarial de uma empresa que tem sua origem na região Norte, que, através de seu processo de evolução, consegue expandir sua estrutura para outras regiões do país. A primeira seção fará uma abordagem teórica sobre história econômica e história de empresas. A segunda seção tratará da origem da empresa e a terceira seção dissertará sobre a sua expansão. A quarta seção abordará sua expansão e venda, e por fim as considerações finais.

\section{Empresa e história de empresas}

A história econômica, assim como a história empresarial, são teorias recentes, no entanto, relevantes para a abordagem teórica do problema proposto neste artigo. A teoria que estuda a história empresarial foi idealizada no século XX e tem como principal ícone Alfred Chandler ${ }^{1}$. Seus pressupostos envolvem a trajetória de grandes empresas americanas que se desenvolveram no final do século XIX e início do século XX.

entende que a História Empresarial concentra sua atenção na análise histórica do desempenho e do efeito de certos empresários inovadores individuais ou de certos grupos de empresários de vanguarda. Em contraste, a "história de empresas" ou business history presta especial atenção à análise das mudanças na organização econômica das companhias ou corporações, mudanças que são parte e reflexo das transformações econômicas e sociais em seu conjunto. (Marichal, 1997, p. 10, apud Saes, 1999, p. 2)

1 “o que Chandler fez não foi recuperar um campo imprestável para semear, e sim fundar a história empresarial como área de estudo independente e importante." (McCraw, 1998, p. 19) 
Pode-se dizer que tanto o empresário quanto a empresa são partes integrantes da história, pois a empresa surge a partir do empresário, sendo propriamente uma construção idealizada por um empreendedor. Portanto, torna-se necessário entender cada uma das partes para poder compreender o todo.

\subsection{0 crescimento da firma e sua história}

De acordo com Penrose (2006), o estudo do crescimento da firma e a sua história tem bastante importância, haja vista que o crescimento leva em si a um aprimoramento de sabedoria que é agregado dentro dos propósitos de evolução da firma. O termo crescimento é utilizado tanto no aumento da produção, quanto no acréscimo de tamanho.

Um dos pressupostos primordiais da teoria do crescimento das firmas é o de que "a história tem importância"; esse crescimento é essencialmente um processo evolucionário e está baseado no incremento acumulativo do saber coletivo, dentro do contexto de uma firma dotada de propósitos. (Penrose, 2006, p. 16)

A autora valoriza o conhecimento acumulado ao longo do tempo. Esse conhecimento faz com que a empresa aprimore cada vez mais suas atividades e os fundamentos da sua administração que passa a ser mais “organizacional”. Os administradores vão se especializando com o crescimento da firma, aprendendo a lidar com novidades e surpresas do mercado. Penrose (2006) diz que, nesse processo evolutivo da firma, ela atinge um novo equilíbrio a cada momento. $O$ novo equilíbrio não pode ser "estático" como na teoria neoclássica, mas precisa ter o equilíbrio "das ações e das ideias", que em momentos de harmonia tomam decisões sobre o seu futuro. Mesmo assim, não existe um equilíbrio duradouro, para a autora o equilíbrio econômico é considerado um "equilíbrio razoável".

A firma ${ }^{2}$ vive no seu "entorno", essa expressão significa que o entorno é mutável e a firma pode modificar ou ser modificada pelo meio

2 Firmas são unidades mercantis. O sistema econômico, em si, define-se pelo tipo de firmas que fazem parte da sua economia (Penrose, 2006). 
em que está inserida, procurando novos territórios e novos ambientes para a sua expansão. O “crescimento da firma”, inicialmente, é analisado pelo seu crescimento interno e subsequentemente passa a ser analisado por sua diversificação e consequentemente pelo aumento das suas instalações.

Trata-se de instituições complexas que influenciam a vida econômica e social de diversas maneiras, envolvendo numerosas e diferentes atividades, tomando uma ampla variedade de decisões significativas, influenciadas por caprichos humanos múltiplos e imprevisíveis, embora geralmente orientados pela luz da razão. (Penrose, 2006, p. 42)

Sabe-se que, no limiar da economia capitalista, muitos são os exemplos de empresas de sucesso que atravessaram os tempos e também muitas firmas deixaram de crescer, não conseguindo chegar à maturidade como empresa e como empreendimento. Assim, as firmas possuem uma alta "taxa de mortalidade" na economia capitalista.

Muitas firmas deixam de crescer por uma variedade de motivos: direção pouco empreendedora, administração ineficiente, incapacidade de levantar capitais em quantidade suficiente, falta de adaptabilidade às circunstâncias mutáveis, juízos deficientes levando a erros frequentes e custosos ou simplesmente falta de sorte devida a circunstâncias fora do controle das firmas. (Penrose, 2006, p. 39)

Penrose (2006) afirma que o conceito de empresa e de empreendedorismo é evasivo, sendo dificil de ser analisado dentro de uma "análise econômica formal", porque esses conceitos estão diretamente ligados a indivíduos, às características desses indivíduos, como seu temperamento, assim como suas qualidades pessoais que fazem parte do seu psicológico. A autora define uma empresa como "uma predisposição psicológica por parte de indivíduos para assumir riscos na expectativa de um ganho e, particularmente, de dedicar esforços e recursos a atividades especulativas" (Penrose, 2006, p. 72). Já o empreendedorismo parte de uma "decisão empresarial", na qual o empreendedor não se preocupa com o tempo do investimento.

No âmbito temporal da firma, o seu mundo é dividido em "adaptações de curto prazo e longo prazo". O curto prazo pode ser definido 
como as decisões cotidianas, que são pertinentes ao seu dia a dia ou mensalmente. As decisões sobre as suas atividades rotineiras geralmente são tomadas por cada setor. Já o longo prazo são as adaptações de "longo alcance", não rotineiras, pelas quais são definidas políticas pela administração central que envolve os principais atores da sua administração (Penrose, 2006).

\subsection{História econômica com enfoque em história empresarial}

Alfred Chandler, estudando as trajetórias das grandes empresas americanas, chegou à conclusão de que a organização da empresa e a sua administração está intimamente ligada com a sua expansão. Ou seja, a sua estratégia define a estrutura e o desenvolvimento da empresa (Campello, 2004). A empresa nos trabalhos de Chandler é definida como um agente econômico responsável pelo processo de produção e distribuição (Cury, 2006).

Para Chandler as empresas americanas foram responsáveis pela ascensão dos Estados Unidos como potência econômica mundial (Chandler, 1991, apud McCraw, 1998). Em torno disso, procurou descrever os processos de mudanças nas estratégias e nas estruturas dessas empresas. Os empresários, percebendo essas mudanças, evoluíram e isso transformou o modelo administrativo até então vigente. As mudanças demográficas e tecnológicas são percebidas por alguns empresários, que de certa maneira reagem de forma criativa e conseguem obter lucro com a nova trajetória, sendo as decisões tomadas de forma racional pelos grandes líderes empresariais.

Para Chandler, "as mudanças nos métodos organizacionais e nas técnicas de comercialização foram, sobretudo, uma reação aos avanços tecnológicos" (Chandler, 1991, apud McCraw, 1998, p. 61). No final do século XIX e início do século XX, as formas organizacionais das empresas se tornaram a "unidade básica da indústria norte-americana".

O advento da grande organização industrial verticalmente integrada, centralizada e departamentalizada modificou as situações interna e externa em que se tomavam as decisões empresarias. As informações sobre mercados, suprimentos e desempenho operacional, bem como as propostas de ação, tinham geralmente que ascender aos vários níveis da hierarquia de- 
partamental, enquanto as decisões e sugestões baseadas nesses dados tinham que descer pela mesma escala para serem implantadas. (Chandler, 1991, apud McCraw, 1998, p. 63)

Esse processo foi uma espécie de burocratização da empresa internamente, enquanto isso externamente nasciam grandes oligopólios na indústria norte-americana.Além de descentralizar ${ }^{3}$, as empresas passaram a diversificar ${ }^{4}$, investir em pesquisa e desenvolvimento, sendo que esses três pilares passaram a fazer parte das estratégias empresariais. Novos produtos passaram a ser lançados em tempos cada vez mais curtos, possibilitando às empresas que investiam mais em pesquisa e desenvolvimento terem uma maior variedade de produtos (Chandler, 1991, apud McCraw, 1998).

Com isso a empresa industrial se tornou um agente de vontades próprias, separou-se do empresário humano para se tornar um "organismo econômico autônomo".A empresa passa a ser maior que os indivíduos que a criaram e que a dirigem, os homens passam a ser componentes de uma esfera administrativa "organizacional”. A administração passa a ser responsável pelo total desempenho da empresa, desde a coordenação, como avaliação, chegando aos recursos humanos da empresa.

\section{Origem e crescimento da Perfumarias Phebo, 1930-1960}

O grande interesse pela história de uma empresa tem como fundamento estudar o passado e as suas principais etapas de desenvolvimento. Esta seção buscará abordar o surgimento, sua evolução e sua trajetória empresarial da Perfumarias Phebo.

\subsection{Os primórdios da industrialização paraense}

A história econômica da Amazônia demonstra que sua economia

3 Estruturas descentralizadas, cada um é responsável pelo seu departamento (McCraw, 1998).

4 "Desenvolvimento de novos produtos para novos tipos de mercado." (McCraw, 1998, p. 191) 
evoluiu a partir das "drogas dos sertões" e da borracha. As exportações sempre estiveram ligadas a produtos como cacau, arroz e cravo, que, durante o final do século XVIII e início do século XIX, foram os principais produtos exportados pela Amazônia.A economia do Pará já vinha explorando a sua riqueza desde o século XVII, sendo que a criação da Companhia Grão-Pará e Maranhão (1756-1778) foi de suma importância para o desenvolvimento do comércio regional. A rota marítima Belém-Lisboa realizada pela empresa possibilitou a coleta das chamadas "drogas do sertão" e a sua comercialização no mercado europeu. Isso fez com a economia da Amazônia tivesse um pequeno avanço no final do século XVIII e início do século XIX (Santos, 1980).

No final do século XIX e início do século XX, houve um crescimento na demanda internacional pela borracha, aumentando e incentivando sua produção. Com isso, Belém tornou-se o centro de negociação e comercialização da borracha no mundo. A economia da borracha contribuiu para a evolução do comércio e para que pequenas indústrias surgissem na cidade. Segundo Santos (1980), com o "colapso” do preço da borracha no período entre 1911 e 1914르, as indústrias locais já apontavam um pequeno avanço.

Várias empresas surgiram depois do boom da borracha, no final do século XIX e início do século XX. Segundo Mourão (1989), após o ciclo da borracha, a cidade de Belém foi berço de desenvolvimento de inúmeras empresas. Entre elas, podem-se destacar fábricas de fumo, cerveja, perfumaria, produtos ligados a borracha etc. Significou um momento de esplêndido crescimento da atividade comercial em Belém e com isso se desenvolveu a sua urbanização, a criação de novos bairros e a ocupação dos igarapés. "Belém era a grande porta de saída do produto, com 125.000 habitantes e um vasto conjunto de casas comerciais" (Martinelo, 1988, p. 47). Com a crescente demanda mundial da borracha devido, principalmente, à fabricação de pneus para automóveis, a cidade viveu uma grande expansão urbana e econômica.

A crise da borracha possibilitou o direcionamento dos investimentos para outras atividades. Segundo Costa (1993), o período de 1910-1921

5 O preço da borracha caiu devido à grande produção asiática. "O fenômeno asiático é que a produção subiu de 3.000 quilos em 1900 para acima de 28.000 .000 de quilos em 1912." (Santos, 1980, p. 237) 
foi marcado pela decadência da borracha na Amazônia, fecharam-se seringais e a região deixou de ter a renda que havia se transbordado com o período áureo e levou a economia local à busca por novas alternativas. Schumpeter (1982) afirma que é em momentos de desenvolvimento turbulento que, geralmente, surgem as inovações. E com isso várias empresas com grande representação econômica para o Estado surgiram em Belém, no final do século XIX e início do século XX. Entre tantas, pode se destacar algumas, como a Fábrica Perseverança, a Fábrica Palmeira e a Perfumarias Phebo.

A Perfumarias Phebo, cuja história é o objeto de pesquisa deste trabalho, foi fundada por volta de 1924, com produtos que se tornaram referência em todo o Brasil. Uma empresa que surgiu a partir de uma família de imigrantes portugueses e que será mais bem descrita e analisada nas partes seguintes.

\subsection{A nascente Perfumarias Phebo}

A história da Perfumarias Phebo começa com a família Santiago, imigrantes portugueses que se instalaram na cidade de Belém, no início do século XX. O patriarca da família era João da Silva Santiago, que possuía uma fábrica de cigarros chamada Minerva.

No Brasil, no início do século XX, os imigrantes eram os maiores comerciantes e industriais (Marcovitch, 2006). Na época, o industrial era visto como uma classe inferior, pois se valorizava o grande dono de terras como expoente de poder e status social. Assim, restava para os imigrantes a função de comerciante e industrial (Lobo, 1997).

Os portugueses se tornaram os principais comerciantes no início do século XX, na cidade de Belém. Para Santos (1980), no auge da produção da borracha, na segunda metade do século XIX, deu-se uma especialização na economia gomífera. Os americanos, ingleses e franceses ficaram responsáveis pela exportação da borracha, enquanto os portugueses, na sua maioria, ficaram com a incumbência do comércio e das pequenas indústrias. Geralmente, a acumulação de capital se dava de forma endógena, em que o lucro era reinvestido na própria empresa.

Os portugueses da família Santiago iniciaram a sua trajetória empresarial com a Fábrica de Fumos Minerva Ltda. Toda a família estava envolvida na produção e comercialização de charutos, cigarros e fumo de 
um modo geral. A empresa familiar era comum entre os imigrantes que vieram para o Brasil. Essa fábrica teve grande importância para a família, pois seria a base de sustentação da perfumaria no auge da crise econômica mundial de 1929.

Mesmo atuando no mercado de fumos, a família Santiago procurou diversificar os seus negócios, participando de uma sociedade em uma fábrica de chapéus em 1924. Essa fábrica se chamava A. L. Silva Companhia Limitada, em que os sócios eram João da Silva Santiago, Maximino Rodrigues da Costa, Manoel Rodrigues da Silva e Manoel Alves Ferreira. A fábrica ficava localizada na Rua 28 de Setembro, n. 194, na cidade de Belém (Pará, 1987).

O comércio de chapéu não estava indo bem, pois o chapéu já entrava em desuso, além da concorrência com os chapéus importados. Percebendo o momento dificil, os Santiagos resolveram diversificar sua produção em torno de produtos de perfumaria. A empresa começou a fabricar uma loção chamada Estrela, que seria a primeira indicação de mudança em direção ao ramo de perfumarias (Santiago, 2009).

Com essa mudança foi criada a Sociedade A. L. Silva Companhia Limitada, estabelecida juridicamente em 4 de fevereiro de 1931 pelos portugueses Maximino Rodrigues da Costa, Manoel Rodrigues da Silva, Manoel Alves Ferreira, João da Silva Santiago e Antônio Leal Gomes da Silva Santiago. No entanto, pelo que consta nas duplicatas antigas, a empresa já funcionava desde 1924, fato corroborado por duplicata de Hermínio Cosme, da cidade de Capanema.

$\mathrm{Na}$ década de 1930, a A. L. Silva recebeu como pagamento de uma dívida a Perfumaria Lusitana.A partir da incorporação dessa perfumaria, a empresa passa a dedicar-se à produção de perfumaria, principalmente sabonetes. $\mathrm{Na}$ época, a maior concorrência era dos sabonetes ingleses que eram importados pelos comerciantes de Belém (Santiago, 2009).

A estrutura da empresa foi dando lugar às essências e aos cheiros dos sabonetes, perfumes, talcos, pó de arroz, pasta dental e outros produtos. A empresa fabricava uma variedade de produtos ligados a limpeza e a higiene pessoal, entre eles o sabonete Damasco, sabonete Londrino, sabonete Favorito, dentifrícia (pasta dental), água dentifrícia para melhorar o hálito bucal, assim como loções para os cabelos. 
Fotografia 1 - Rótulos dos sabonetes Damasco, Londrino e Favorito da Perfumaria Luzitana

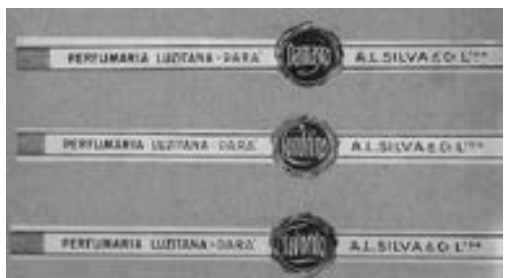

Fonte: Arquivo Sônia Santiago.

A figura acima mostra rótulos dos sabonetes que eram produzidos pela Perfumaria Lusitana ou Luzitana ${ }^{6}$. Abaixo uma "água dentifrícia”, que era um enxaguante bucal com ação anticéptica, que prometia limpar os dentes e cuidar do hálito, tendo sabor refrescante e uma ação forte.

Fotografia 2 - Água dentifrícia da A. L. Silva Companhia Limitada

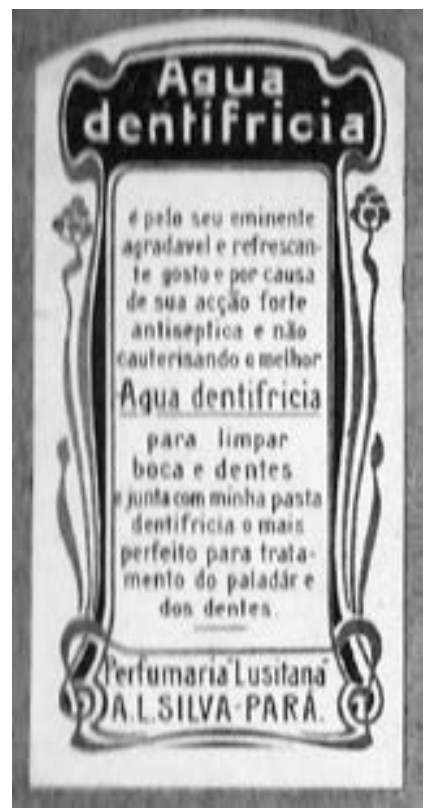

Fonte: Arquivo Sônia Santiago.

6 Não se sabe se o verdadeiro nome era Lusitana ou Luzitana. 
Por ser uma empresa familiar, a A. L. Silva tinha no seu quadro de funcionários os irmãos Mário Gouveia Santiago, Sílvio Gouveia Santiago e Antônio Santiago, os primeiros eram filhos e o último, sobrinho de João Santiago. A família era responsável por todo o processo de fabricação dos produtos.

A grande inovação da A. L. Silva ainda estaria por vir. Baseado no sabonete Pears Soap ${ }^{7}$, a empresa inovou e passou a fabricar um produto similar. A ideia seria utilizar o modelo do sabonete inglês, mas com um toque regional. Depois de muita pesquisa e muitos testes, veio a ideia de produzir o sabonete à base de "pau-rosa", que era uma matéria-prima oriunda da Amazônia e muito utilizada na época. Esse sabonete se tornaria o principal produto da empresa, cujo nome final seria Phebo Odor de Rosas.

No início o nome do sabonete tinha em si o reflexo do sabonete inglês, que se chamava London Otto Rosa. A empresa nunca negou a "imitação" e a referência ao sabonete inglês. Essa foi uma estratégia de mercado aproveitada para promover o sabonete preto que a empresa passou a fabricar. Mais tarde, o London Otto Rosa passou a se chamar Londres Odor de Rosas. Porém, quando se foi registrar o produto, já havia outra marca registrada com esse mesmo nome. Foi daí que Antônio Santiago sugeriu o nome Phebo, em analogia ao deus do Sol na mitologia grega. O sabonete Phebo Odor de Rosas popularizou-se e tornou-se um sucesso (Santiago, 2009).

No início, o sabonete Phebo era produzido utilizando um tambor de 100 litros. A produção era feita de maneira artesanal, a família fabricava o sabonete em casa, em um fogão a lenha. $\mathrm{Na}$ época o sabonete demorava cerca de seis meses para ficar pronto. O sistema de secagem exigia muito tempo e era necessário um longo período na estufa para ficar totalmente seco. Caso contrário, secava-se por fora, mas por dentro do sabonete ficava gelatinoso (Phebo, 1988).

O produto era dirigido a uma classe social mais alta, sendo mais caro que os sabonetes populares. Naquela época se via o produto importado como algo melhor do que o nacional. Como as importações dos sabonetes ingleses ficaram mais restritas, abriu-se o caminho para a consagração do sabonete Phebo no mercado local e nacional. A elite local adotou

7 Um sabonete inglês muito utilizado na época. 
esse sabonete como um substituto perfeito do sabonete inglês Pears Soap (Santiago, 2009).

Fotografia 3 - Panfleto do sabonete Phebo, 1931

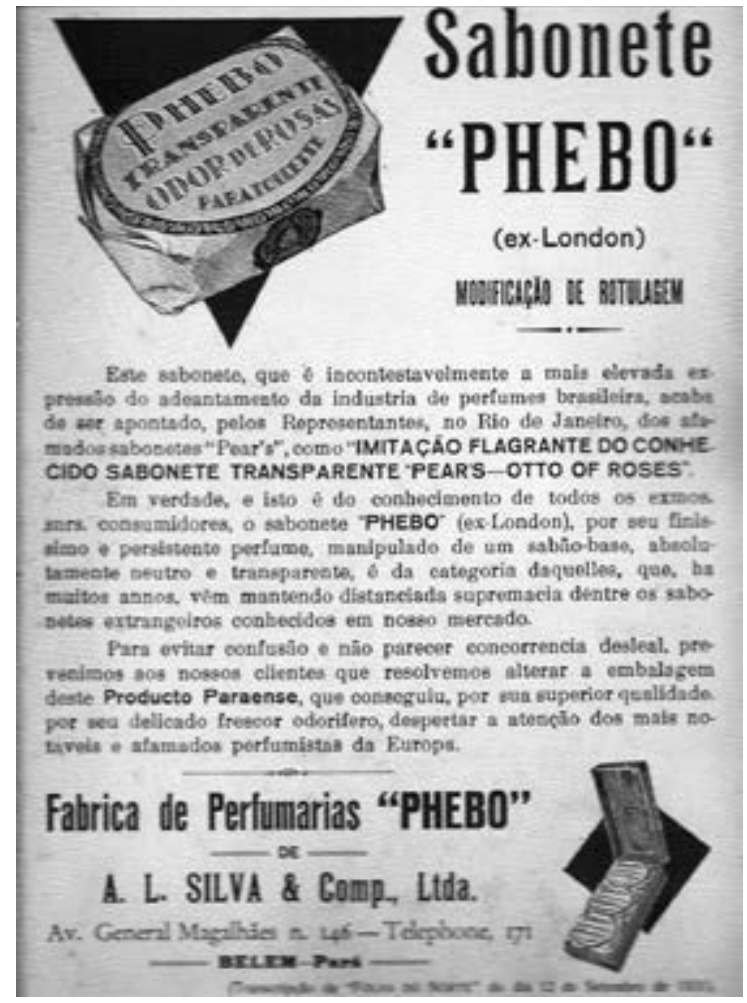

Fonte: Arquivo Sônia Santiago.

$\mathrm{Na}$ figura acima, observa-se uma propaganda da empresa no jornal Folha do Norte de 1931, que deixa claro no panfleto que o sabonete Phebo é uma "imitação flagrante do conhecido sabonete transparente da época, o Pear's - Otto of Roses". No entanto, enfatiza a qualidade diante dos estrangeiros, destacando que se tratava de um produto inteiramente paraense. Apesar do grande volume de vendas do sabonete Phebo, a empresa viveu momentos de crise. Houve grandes perdas com a crise financeira mundial de 1929 e o volume de vendas do sabonete não foi suficiente para sustentar os custos e as perdas com a crise; naquele 
momento a empresa teve que recorrer ao aporte financeiro do outro negócio da família, a Fábrica de Fumos Minerva Ltda.

A recuperação viria apenas em 1936, e foi aí que resolveram mudar a razão social, passando a se chamar Perfumarias Phebo Limitada.A nova empresa se deu devido à fusão da A. L. Silva Companhia Limitada com a Fábrica de Fumos Minerva Ltda. O nome Phebo já estava sendo usado desde 1931 como nome fantasia e em 1936 houve apenas uma concretização jurídica (Phebo, 1988).

\subsection{A criação da Perfumarias Phebo Limitada}

De acordo com os dados da Junta Comercial do Estado do Pará (JUCEPA), em 28 de fevereiro de 1931 foi arquivada a escritura pública de constituição da sociedade A. L. Silva Companhia Limitada e em 20 de junho de 1936 ocorre a mudança da razão social, passando a se chamar Perfumarias Phebo Limitada.

Nesta época, os principais acionistas estavam representados por:JOÃO DA SILVA SANTIAGO, MAXIMINO RODRIGUES DA COSTA, MANOEL RODRIGUES DA SILVA, MANOEL ALVES FERREIRA, ANTÔNIO SANTIAGO,JOSÉ DE SOUZA RAMO (diretor comercial), MÁRIO SANTIAGO E SILVIO GOUVEIA SANTIAGO (irmão de Mário Santiago). (Phebo, 1988, p. 3)

Ao transformar o nome fantasia da empresa em razão social, a empresa aproveitou para incorporar o jovem Mário Santiago e o irmão Sílvio Santiago como sócios da empresa, aumentando também o seu capital social de 200 contos de réis para 500 contos de réis, que foi devidamente dividido entre os sócios em razões proporcionais e estabelecidas as regras da sociedade.

A Phebo passou a ter oito sócios, com cotas maiores para João Santiago e Maximino Rodrigues da Costa. Já Manoel Rodrigues da Silva, Manoel Alves Ferreira e Antônio Leal Gomes da Silva Santiago tiveram suas cotas integralizadas na sociedade que possuíam com A. L. Silva Companhia Limitada. E as cotas de José de Souza Ramos, Mário Gouveia Santiago e Sílvio Gouveia Santiago seriam integralizadas pelos lucros futuros que a empresa por ventura pudesse conseguir. E assim 
foram nomeados gerentes Antônio Santiago, Mário Santiago, José de Souza Ramos e Sílvio Gouveia Santiago.

No ano de 1937, devido à expansão dos seus lucros, a Phebo ampliou sua fábrica incorporando uma nova empresa a sua estrutura, a Perfumarias Salim Salles, que ficava localizada na Travessa Quintino Bocaiúva n. 325, na cidade de Belém (Pará, 1987). A empresa de Salim Salles era uma perfumaria de grande destaque:

A "Fábrica de Perfumarias Paraenses", do Sr. Salim Salles \& Cia, possuía oficinas para estamparia em metais, fabricação de latas e obras em folha de flandres, tipografia, encadernação e caixas de papelão, além das aperfeiçoadas oficinas de produção da saboaria, perfumes e cosméticos diversos. (Mourão, 1989, p. 56)

Na década de 1940, devido à Segunda Guerra Mundial, a Phebo vivenciou uma crise por falta de matérias-primas, em virtude de a maioria dos seus insumos serem de origem estrangeira. "A falta de suprimento de essências aromáticas então importadas e de outras matérias-primas principais, aliada aos decréscimos do poder aquisitivo e a consequente queda no consumo, obrigaram a empresa a paralisar sua produção" (Phebo, 1988 , p. 5). Isso fez com que a Phebo procurasse flexibilizar sua estrutura produtiva, passando a atuar com mais dedicação no mercado de embalagens.

A empresa começou a fabricar vasilhames para a coleta de látex nos seringais. Na época, a Phebo já possuía uma carpintaria e uma tornoaria, onde fabricava as embalagens de madeira e também vasilhames de lata para seus produtos. Além disso, criava seus próprios rótulos, e a empresa foi uma precursora em maquinários de prensa e litografia ${ }^{8}$. A própria empresa imprimia nos sabonetes os seus desenhos e sua marca.

Para feitura de rótulos dispomos de oficinas de tipografia e litografia. Para as caixas de madeira, tão apreciadas pelas senhoras e senhoritas que nos honram com a sua preferência, temos uma serraria e uma tornoaria. Agora sentimos dificuldades no que refere às latas, por falta de folhas de Flandres, de que a praça tem pouco estoque. (Folha do Norte, 1954?, p. 3)

8 Escrita em pedra e impressa em papel. 
A tipografia era o local onde as embalagens eram elaboradas e rotuladas nos produtos. A máquina de litografia ocupava uma sala espaçosa e ampla, essa máquina fazia o trabalho em zinco e era importada dos Estados Unidos. Mas, durante a Segunda Guerra Mundial, a Phebo adaptou-a para realizar o trabalho também em papel. A Phebo era autossuficiente na produção das suas embalagens. Isso se deve ao fato de estar longe dos grandes centros; por isso, na tentativa de não depender de outros fornecedores, dominava todos os processos da produção (Folha do Norte, 1954?).

Essas embalagens eram criadas adaptando-se as características das matérias-primas regionais com o uso de caixas em madeira. Penrose (2006) destaca que a produção de produtos intermediários ao funcionamento é feito pelas firmas como estratégia para o seu crescimento. A autora chama a isso de "integrar-se para trás", quando a firma começa a produzir itens que poderiam ser adquiridos de terceiros. A firma enxerga a integração para trás como uma forma de reduzir os seus custos. No caso da Phebo, isso é bem claro, pois ficava muito caro para a empresa adquirir produtos de outras regiões mais distantes, por conta da precariedade dos meios de transportes da época.

Apesar de os perfumes serem produzidos no laboratório da própria Phebo, as matérias-primas, como os produtos químicos e essências, eram importados. Antes da Segunda Guerra Mundial, a importação das matérias-primas eram oriundas dos Estados Unidos. Após a Segunda Guerra, passou-se a importar da Europa, principalmente da França (Folha do Norte, 1954?).

Após a Segunda Guerra Mundial, a empresa retornou ao seu pleno funcionamento e deu início ao seu crescimento e à sua consolidação no mercado de perfumaria nacional. Por volta de 1950, a Phebo criou outro produto que se tornaria um referencial de consumo no Brasil, a Seiva de Alfazema da Phebo. Aponta Santiago (2009) que Mário Santiago viajou à França em busca de essências para compor o produto e chegou a uma fragrância leve e suave do produto. No início a seiva de alfazema era comercializada em garrafas de meio litro. $\mathrm{Na}$ época a empresa tinha também uma linha de produtos chamada Madeira da Amazônia, que fez muito sucesso durante a década de 1950. A Madeira da Amazônia era uma caixa com um kit de produtos da Phebo.

Caracterizado o seu crescimento, a empresa decide em 31 de outu- 
bro de 1957 alterar seu contrato social, passando de Sociedade Limitada para Sociedade Anônima, mudando a sua razão social para Perfumarias Phebo S/A (Pará, 1987).

Em 1957, os seus dirigentes, prevendo o crescimento da empresa e a necessidade de ampliar suas atividades em todos os setores - produção, distribuição e vendas - e visando dotá-la de uma forma jurídica compatível não só com o desenvolvimento econômico do país, mas ainda com as técnicas de administração e de gestão internas, propôs e efetivou em 15 de outubro do mesmo ano a transformação jurídica da empresa de Limitada para Sociedade Anônima, com razão social de Perfumarias Phebo S/A. (Phebo, 1988, p. 6)

Em 1959 a empresa investiu na melhora do setor de distribuição. Esse era um grande problema para as empresas locais devido às grandes dificuldades de logística para escoar a produção para outras regiões. Nesse ano, o crescimento da empresa era visível, tendo arrecadado naquele ano aos cofres públicos Cr\$50.183.956,80 em impostos (municipal, estadual e federal). Após a sua transformação em empresa de S/A (Sociedade Anônima), a Phebo teve um crescimento considerável. No período de 1957 a 1960, o lucro da empresa foi crescente, o empreendimento ganhava força e desenvoltura para a sua expansão para a cidade de São Paulo.

Os números do período apontam que o passivo superou a evolução do ativo. No entanto, o lucro da empresa continuou positivo e crescente, tendo também o seu patrimônio líquido aumentado mais de três vezes de valor de 1957 para 1960. Isso configura que a empresa estava em perfeitas condições de normalidade e o seu lucro cresceu em todos os anos, no período de 1957-1960.

Tabela 1 - Balanço patrimonial (resumo), 1957-1960, em cruzeiros (corrigido para Cr\$ $\$$ 1960)

\begin{tabular}{|c|c|c|c|c|}
\hline ANO & $\begin{array}{c}\text { Ativo } \\
\text { CIRCULANTE }\end{array}$ & $\begin{array}{c}\text { Passivo } \\
\text { CIRCULANTE }\end{array}$ & $\begin{array}{c}\text { ReSUltado } \\
\text { (LUCRO OU PREJUÍZO) }\end{array}$ & $\begin{array}{l}\text { PATRIMÔNIO } \\
\text { Ĺ́QUIDO }\end{array}$ \\
\hline 1957 & 117.816 .976 & 52.177 .751 & 23.793 .829 & 92.599 .535 \\
\hline 1958 & 136.679 .551 & 75.064 .851 & 31.913 .467 & 89.503 .169 \\
\hline 1959 & 154.235 .683 & 97.133 .815 & 26.574 .115 & 117.443 .822 \\
\hline 1960 & 165.908 .344 & 99.775 .175 & 31.719 .964 & 125.711 .771 \\
\hline
\end{tabular}

Fonte: Balanço Phebo (1957-1960). 
No período acima, o patrimônio líquido da Phebo foi positivo, tendo tido apenas uma variação negativa no ano de 1958. O seu ativo circulante cresceu a um ritmo menor que o passivo, isso pode significar que os débitos estavam crescendo mais rápido que os créditos. No entanto, o lucro da empresa esteve em ascensão, com exceção para o ano de 1959, que teve uma variação menor que o ano de 1958. O grande problema para a Phebo nesse período era o seu sistema de distribuição, o que requeria maior atenção dos seus diretores, pois, no estado do Pará, o transporte rodoviário e marítimo era precário.

\section{Expansão e consolidação, 1961-1988}

\subsection{Transformações do orgânico para o sintético e a expansão para o Sudeste}

No final da década de 1950, a empresa conseguiu aumentar suas vendas para a região Sul do país, tendo como principais mercados consumidores São Paulo, Rio de Janeiro, Belo Horizonte e Rio Grande do Sul. O sabonete Phebo se tornou um produto que o Brasil inteiro usava (Santiago, 2009). Com o aumento da produção, a empresa modifica sua estratégia de uso das matérias-primas, abandona a utilização de matéria-prima orgânica, como óleo de pau-rosa, e passa a utilizar a essência sintética.

Com a ampliação do mercado consumidor para os seus produtos em 1960, a Phebo toma a decisão de criar uma filial na cidade de São Paulo. Mário Santiago, presidente da empresa, percebeu que a Phebo estava diante de um problema muito difícil. A maioria das matérias-primas, principalmente os insumos químicos, utilizadas na fabricação do sabonete Phebo era de origem paulista. Os insumos vinham de São Paulo e depois os produtos eram fabricados em Belém e retornavam para São Paulo, para serem comercializados.

Mário Santiago percebeu que, se a empresa não fundasse uma fábrica na cidade paulista, perderia competitividade. Nesse momento, decidiu viajar para São Paulo e criar uma filial da Phebo. A partir de 1961, a empresa começa sua trajetória de expansão com a criação da filial na cidade de São Paulo, e outra filial é erguida em Feira de Santana, na Bahia, a chamada Phebo Nordeste. 
$\mathrm{Na}$ filial de São Paulo, a empresa tinha como estratégia um mercado fornecedor de matéria-prima, além de um mercado consumidor. No Nordeste, a filial servia como ponto de distribuição para os estados daquela região. Com isso, a Phebo fez o caminho "periferia-centro", um caminho inverso que naturalmente as empresas costumam fazer. A empresa surgiu na cidade de Belém, num estado com poucas tradições industriais e com grande dificuldade de logística, mas vence e supera as contradições e desigualdades existentes para a indústria de um estado de economia primária, como o estado do Pará, e consegue atingir e se expandir no centro industrial do país, a capital de São Paulo, berço da industrialização brasileira.

A expansão de uma firma pequena é algo difícil, principalmente em mercados nos quais já existam firmas grandes, as quais pela sua robustez podem impedir empresas menores de sobreviverem. No entanto, existem exceções, as firmas pequenas podem sobreviver e até se expandir, mas isso desde que tenham algo vantajoso sobre as maiores.

As firmas pequenas podem sobreviver por causa de alguma pequena vantagem num mercado específico, mas, sob essas circunstâncias, entrantes, se os houver, consistirão de firmas grandes, geralmente oriundas de ramos correlatos, capazes de empreender a necessária expansão. (Penrose, 2006, p. 163)

No caso da Phebo, ela possuía um produto inovador, que ao mesmo tempo levava em si o exótico e o mistério da Amazônia, ou seja, a essência de pau-rosa no sabonete Phebo fez com a empresa lograsse êxito. Tamanho foi o sucesso desse produto, que ele passou a representar a empresa, assim como aconteceu com o Bombril e o Leite Moça, o sabonete Phebo deu nome a Perfumarias Phebo S/A.

\subsection{A consolidação no mercado brasileiro}

Em 1961, a filial paulista da Phebo começou a funcionar com 20 funcionários, e Mário Santiago e a família trabalhavam juntos na produção.A empresa passou a produzir as colônias e os desodorantes, principalmente a Seiva de Alfazema da Phebo, que na época já era um dos seus principais produtos. A unidade de Belém ficou responsável pela fabricação dos sabonetes transparentes, principalmente o sabonete Phebo. 
Mário Santiago ficou à frente da filial de São Paulo, aos poucos a fábrica paulista passou a concentrar o núcleo da administração geral. Essa unidade ficou encarregada do departamento financeiro, do marketing e de toda a parte técnica de embalagem, enquanto a matriz paraense ficou a cargo de Fausto Soares Filho, que foi um grande incentivador para a construção da filial na cidade de São Paulo (Santiago, 2009).

Em 1966, a Phebo consegue um financiamento na SUDAM - Superintendência de Desenvolvimento para Amazônia, através da Lei n. 5.174/66, aprovada em abril de 1967; com isso a empresa passa a ter deduções no imposto de renda (somente na matriz) sobre os seus resultados financeiros. A partir daí, a empresa recebe várias propostas de investidores que desejavam investir suas deduções nos ativos da Phebo. Os diretores tiveram que fazer uma seleção de quais investidores seriam aceitos.

A respeitada tradição da marca PHEBO e o elevado conceito de que desfrutam os dirigentes de nossa companhia em todos os centros empresariais do país, fizeram com que logo chegassem a nós dezenas de cartas de investidores solicitando preferência para aplicarem seus depósitos de imposto de renda no empreendimento fabril por nós projetado, em procedimento espontâneo que muito nos desvanece e estimula. E de tal monta foi essa manifestação que, logo alcançando o limite máximo fixado pela SUDAM, tivemos de rejeitar muitos dos oferecimentos recebidos. (Balanço Phebo, 1967)

A Lei n. 5.174, sancionada em 1966, declarava que pessoas jurídicas de todo o território nacional poderiam aplicar até 50\% do seu imposto de renda em empreendimentos agropecuários e/ou industriais localizados na Amazônia.A empresa que recebesse o incentivo deveria manter o valor das ações ou das isenções em uma rubrica denominada Fundo para Aumento de Capital. Isso possibilitou à Phebo isenção total do imposto de renda incidente sobre os resultados operacionais da matriz em Belém e o recebimento de investimentos de outras empresas do Brasil, localizadas no Sul e Sudeste do país.

$\int 1^{\circ} \mathrm{O}$ valor de qualquer das isenções amparadas por este artigo deverá ser incorporado ao capital da pessoa jurídica beneficiada até o fim do exercício financeiro seguinte àquele em que tiver sido gozado o incentivo fiscal, isento do pagamento de quaisquer impostos ou taxas federais e mantida em 
conta denominada "Fundo para Aumento de Capital" a fração do valor nominal das ações ou o valor da isenção que não possa ser comodamente distribuída entre os acionistas. (Brasil, 1966)

Através dos beneficios fiscais garantidos pela Lei n. 5.174/66, a Phebo ampliou suas instalações em Belém, aumentando a produção dos sabonetes para atender à maior demanda do mercado; na época o sabonete Phebo era os mais procurado. Em 1971, os investimentos realizados no projeto de ampliação da fábrica na capital paraense já somavam Cr\$2.073.363,00 e a previsão era de aumentar em 30\% a produção na filial.

Esses incentivos fiscais eram comuns na época, principalmente para empreendimentos com grande concentração de capital. Costa (2000) aponta que, com a criação da SPEVEA, o governo militar manteve a intenção de desenvolver a Amazônia através desses grandes empreendimentos. Os incentivos fiscais, através da Operação Amazônia, chegaram a cobrir $75 \%$ dos empreendimentos capitalistas na região.A SUDAM aprovou, até 1985 , US $\$ 3.928$ milhões para as empresas, apoiados no Artigo 18, que fornecia financiamentos e incentivos fiscais a grandes empresas.

Além dos benefícios da SUDAM, a Phebo também recebeu os incentivos fiscais da SUDENE - Superintendência de Desenvolvimento do Nordeste, o que possibilitou a Phebo instalar uma nova fábrica na cidade de Feira de Santana, na Bahia. A nova fábrica foi aprovada pela SUDENE no dia 24 de novembro de 1971. Era estimado um investimento de 15 milhões de cruzeiros e, até o final do ano de 1971, já havia sido gasta a cifra de Cr\$1.061.048 (Balanço Phebo, 1971).

Em 1966, após cinco anos de inaugurada a filial na cidade de São Paulo, a Phebo demonstrava grande vigor. No quarto ano de exercício da filial, a produção da empresa já havia aumentado em dez vezes e o resultado do exercício de 1966 mostrava um lucro de Cr\$ 777.765.644. Esse resultado positivo aliado aos incentivos governamentais. Dos Cr $\$ 777$ milhões de lucro daquele ano, Cr\$476.768.577 foram destinados a "lucros suspensos", ficando disponíveis para a Assembleia Geral, e Cr\$128.700.000 desses lucros suspensos foram destinados para a ampliação das instalações industriais (Balanço Phebo, 1965). O financiamento conseguido na SUDAM foi da ordem de Cr\$1.110.000,00. A maior parte desse valor $(\mathrm{Cr} \$ 850.000,00)$ viria através de incentivos fiscais. A outra parte 
(Cr\$260.000,00) foi concedida como crédito (Biblioteca da Superintendência da Amazônia,1967, apud Mourão, 1989, p. 98).

A ampliação da fábrica em Belém tinha como foco a criação de um sistema de tubulação para melhorar e tornar mais rápido a secagem e a solidificação dos sabonetes transparentes. Na sequência a empresa procurou se reestruturar, melhorando a qualidade dos seus produtos. Em 1968, a Phebo criou um laboratório próprio. Já em 1969, aproveitando da elevação nas vendas, a empresa faz a "Revolução da Informática", informatizando todo o seu sistema de faturamento, dando maior agilidade aos pedidos e ao atendimento aos clientes.

No ano de 1970, a empresa procura se profissionalizar e faz uma renovação na sua estrutura funcional. Mário Santiago, através de uma carta registrada em cartório, concede pensão vitalícia para os antigos diretores e contrata novos funcionários, implantando uma administração mais profissional na matriz em Belém. Assim, a empresa entra em um ciclo de profissionalização e passa a investir na capacitação dos funcionários (Balanço Phebo, 1970).

Como sabe a nossa Phebo tem nos últimos tempos alcançado um extraordinário desenvolvimento. Para que ela possa subsistir, tem que manter pelo menos esse mesmo ritmo de crescimento, se não quisermos correr $\mathrm{o}$ grave risco de perecimento num futuro próximo. Ante um mercado que mais se agiganta e se agride a cada ano que passa.Vemos quantas perfumarias por falta de administração, dinamismo e outros fatores têm sucumbido nestes últimos anos de atividade. Faliram, simplesmente desapareceram ou então estão a ponto disto, firma como Flamor,Valerri, Sandaco e até a Grande Beija-Flor que por tantos anos foi líder de mercado na década de 30 a 50. Para que não ocorramos tão grave risco, faz necessário todo empenho, todo entusiasmo, todo dinamismo de comandantes e comandados imperiosos se torna ainda assimilação da moderna tecnologia em todos os setores da empresa para que ela possa fortalecer e competir nesse mercado altamente evoluído. Sabemos que a idade e o desgaste físico vão minando nossa capacidade de trabalho, limitando-nos gradativamente. É generalizada a norma nos âmbitos nacionais e internacionais particularmente de conceder aposentadoria às cúpulas administrativas aos sessenta e cinco anos de idade. Companhias de maior expressão como General Motors, Ford, Nestlé, Givaldan, Feminish, Santa Marina e tantas outras sistematicamente aposentam os seus diretores aos sessenta e cinco anos. (Balanço Phebo, 1970) 
Nessa carta, Mário Santiago, compreendendo as mudanças que vinham acontecendo tanto no mercado nacional como internacional, usa o exemplo de outras grandes empresas da época e afirma: "para que a Perfumarias Phebo S/A não entrasse em decadência, sua administração precisaria ser dinamizada e modernizada". Isso implicava aposentar os diretores com mais de 65 anos. E, assim, ele concedeu pensão vitalícia a Afonso Mendes, diretor industrial da unidade de Belém na época.

No ano de 1971, a empresa aproveita o grande momento da economia brasileira (o chamado "milagre econômico") para promover outra expansão nos seus negócios. A procura pelo sabonete Phebo havia aumentado no mercado interno.Além disso, a empresa começava a planejar exportações para vários países da Europa, África e América Central. $O$ resultado de tudo isso mostra que naquele ano as vendas aumentaram $21 \%$ em relação a 1970 e o faturamento atingiu 14 milhões de cruzeiros, sendo $34,8 \%$ superior ao ano anterior. O capital social alcançava a casa dos 4,2 milhões de cruzeiros. Então, a Perfumarias Phebo decide abrir o seu capital, lançando no mercado 3 milhões de ações.

Para manter esse avanço no mercado interno e incrementar suas exportações, a empresa desenvolve outro projeto de suma importância para o seu futuro empresarial, a Phebo Nordeste S/A. Essa nova fábrica seria inaugurada na cidade de Feira de Santana, na Bahia, por volta de 1972. Na construção da fábrica mais moderna da Phebo, a SUDENE teve papel primordial. O governo federal financiou praticamente toda a obra, dos cerca de 20 milhões de cruzeiros gastos na construção, 15 milhões vieram da SUDENE (Balanço Phebo, 1971).

A filial baiana ficou responsável pela fabricação dos sabonetes opacos, principalmente os da linha da Turma da Mônica ${ }^{9}$. O principal motivo para a criação dessa fábrica em Feira de Santana deve-se ao fato de a cidade se encontrar em um lugar estratégico para o escoamento da produção para o mercado nordestino. Essa filial "não tinha nenhum membro da família na administração, todos os funcionários [do gerente ao auxiliar] eram rigorosamente contratados" (Vidal, 2009).

9 "Era um terreno imenso porque nesse tempo o governo estava dando esse apoio, esse incentivo, era uma empresa que tinha um enorme coqueiral e a empresa era uma fábrica muito moderna e passou a fabricar o sabonete de massa opaca." (Santiago, 2009) 
No entanto, com as fábricas de Belém, São Paulo e Feira de Santana, a empresa passou a ter problemas com a distribuição dos seus produtos. Como cada fábrica era responsável pela fabricação de um determinado produto, quando se recebia um pedido envolvendo perfumes, sabonetes opacos e transparentes, tinha que sair um pouco de cada fábrica, isso fez com que a empresa aumentasse os seus custos com transportes. O Grupo Phebo chegou a ter cerca de 1.600 funcionários ao todo, só a unidade de Belém teve cerca de 300 funcionários (Vidal, 2009).

\subsection{O sabonete Phebo e a Seiva de Alfazema}

O crescimento da Perfumarias Phebo S/A foi conquistado a partir de produtos-chave: o sabonete Phebo e a Seiva de Alfazema. Esses produtos permitiram à empresa acessar novos mercados e ter maior competitividade.

Fotografia 4 - Sabonete Phebo Odor de Rosas

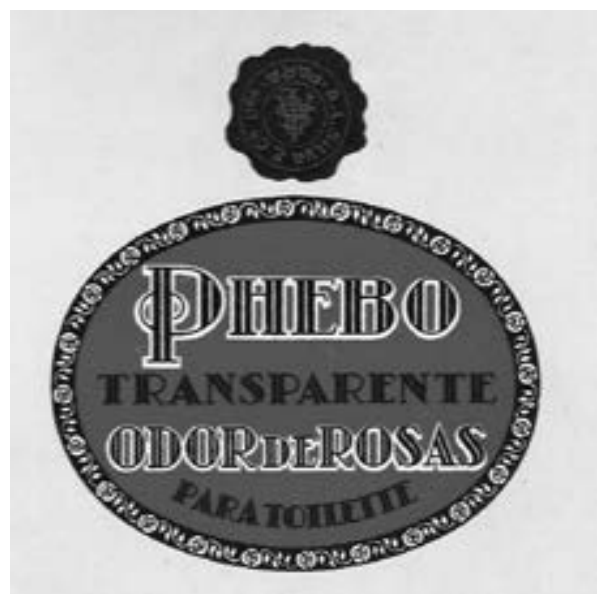

Fonte: Arquivo Sônia Santiago.

O sabonete Phebo sempre foi o principal produto da empresa desde a sua fundação e durante toda a sua história. O sabonete foi o ponto de referência, diferenciado dos demais produtos; a procura era tanta, que a Phebo controlava as suas vendas, pois não conseguia atender a toda a demanda. Era o único sabonete preto no mercado, os vendedores nas 
reuniões reclamavam, exigindo uma maior oferta do produto e solicitavam que a empresa se empenhasse para poder expandir sua produção.

Tabela 2 -Vendas de sabonete Phebo e Pará, 1962-1966

\begin{tabular}{l|c|c}
\hline \multirow{2}{*}{ ANO } & \multicolumn{2}{c}{ VeNDAS (UNIDADES) } \\
\cline { 2 - 3 } & Sabonete Phebo & Sabonete Pará \\
\hline 1962 & 4.701 .924 & 484.596 \\
\hline 1963 & 4.856 .280 & 297.516 \\
\hline 1964 & 4.368 .636 & 315.660 \\
\hline 1965 & 4.733 .232 & 397.788 \\
\hline 1966 & 5.887 .692 & 328.812 \\
\hline
\end{tabular}

Fonte: Ata n. 4, Sexta Reunião da Convenção Geral de Vendedores.

Em 1966, o sabonete atingiu recorde em vendas até aquela data. $\mathrm{Na}$ Sexta Reunião da Convenção Geral de Vendedores, realizada na cidade de Belém, em janeiro de 1967, na sede do HotelVanja, a empresa comemorava esse grande acontecimento. O sabonete vendeu aproximadamente 5,9 milhões de unidades, um número $24,4 \%$ maior em relação ao do ano de 1965.

Fotografia 5 - Sabonete Pará da Phebo

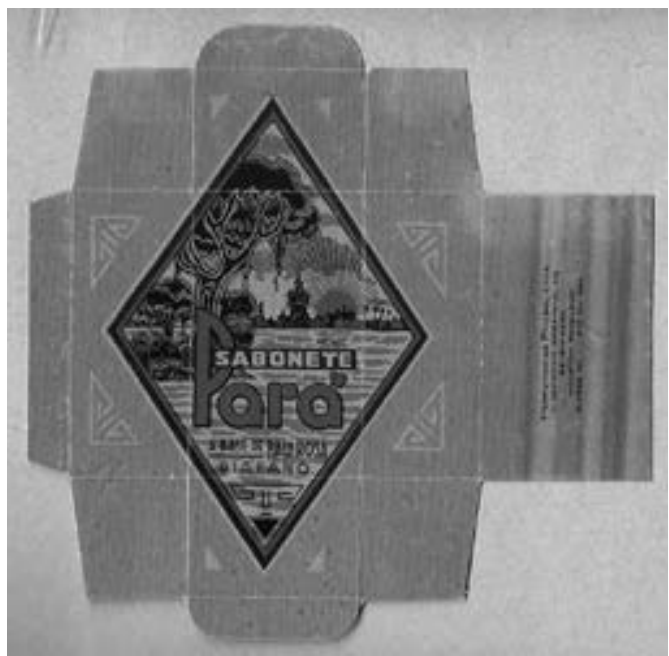

Fonte: Arquivo Sônia Santiago. 
Com isso o sabonete Phebo se consolidava cada vez mais como o maior produto da empresa. Fazendo uma comparação com o sabonete Pará, a venda do Phebo foi aproximadamente 18 vezes maior e a empresa só não vendeu mais por falta de capacidade para atender a toda a demanda. Na época, Fausto Soares Filho, que era diretor comercial da empresa, lamentava aos seus vendedores a dificuldade em atender a determinadas regiões do país, pois existiam problemas com a logística, principalmente na região Norte. Outro produto de referência em vendas na Perfumarias Phebo foi a Seiva de Alfazema. Muito utilizado pela população brasileira, principalmente em crianças recém-nascidas, o produto é lembrado pela suavidade de sua fragrância.

Fotografia 6 - Seiva de Alfazema da Phebo

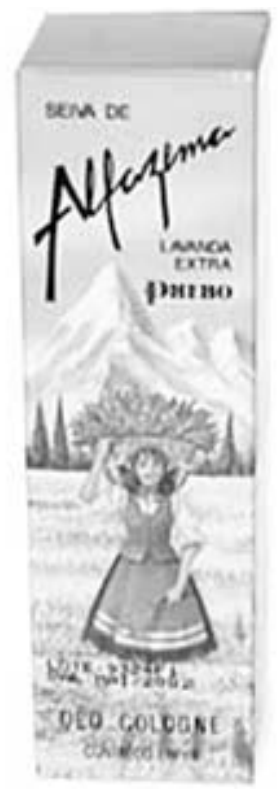

Fonte: Arquivo Sônia Santiago.

Em 1980, a empresa conquistou um dos maiores prêmios da propaganda mundial, o Prêmio Leão de Ouro de Cannes, na França. O comercial da Seiva de Alfazema produzido por Vander Cairo Levi ficou em segundo lugar e rendeu esse título a Perfumarias Phebo S/A. A propaganda tinha a intenção de atingir o público mais jovem e nela aparecia 
uma mulher usando Seiva de Alfazema e uma menina tentando imitar a mãe. Na época o comercial foi uma das maiores conquistas da propaganda brasileira. O publicitário Vander Cairo Levi foi o produtor do comercial: "a característica do perfume é uma coisa suave, muito floral, muito do Alpes, um negócio fantástico.É um prêmio muito importante, basta dizer que tem 4 mil comerciais no mundo inteiro" (Balanço Phebo, 1980).

Através dos seus dois principais produtos, o sabonete Phebo e a Seiva de Alfazema, a Phebo se manteve entre as principais empresas de perfumaria do país. Nas décadas de 1970 e 1980, mesmo com a grande concorrência das empresas multinacionais, como Unilever, Johnson \& Johnson e outras, a empresa se manteve sólida até o dia da sua venda.

Gráfico 1 - Phebo: trajetória e classificação entre as maiores empresas de perfumaria do Brasil

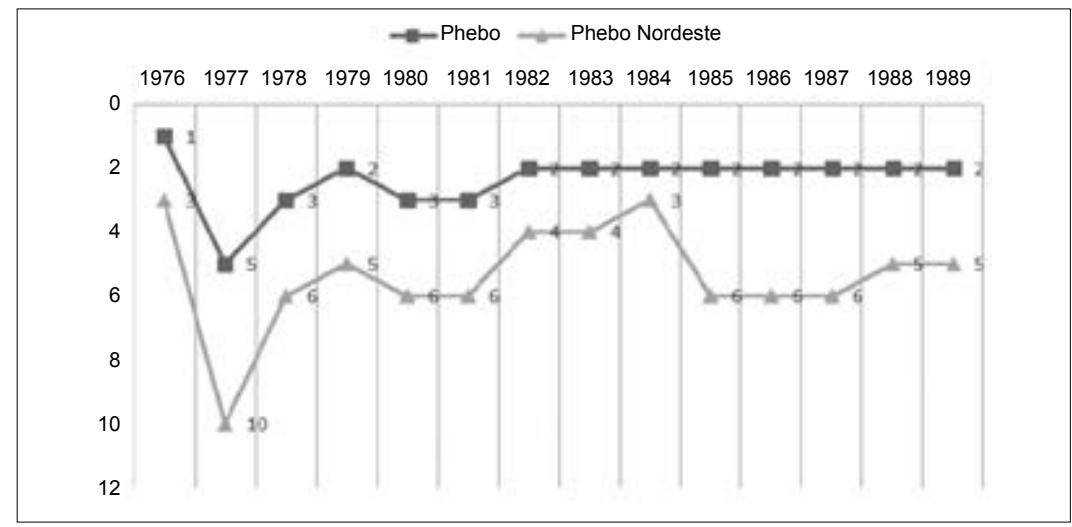

Fonte: Balanço anual, Gazeta Mercantil (1976, 1977, 1978, 1980, 1981, 1982, 1983, 1984, 1985, 1986, 1987, 1988,1989).

Baseado nas publicações da Gazeta Mercantil, que avalia as principais empresas da economia brasileira, traçou-se uma trajetória e classificação da Perfumarias Phebo em relação a outras empresas do ramo de perfumaria e sabonete. A Phebo juntamente com a Phebo Nordeste, fábrica de Feira de Santana, estiveram entre as principais empresas brasileiras do setor de perfumaria no período de 1976 a 1989 e as duas empresas demonstraram que os produtos da Phebo já atingiam uma escala abrangente no mercado nacional. A empresa tinha a convicção de que o mercado estava se profissionalizando cada vez mais e que a entrada das grandes 
multinacionais no setor era algo inevitável. Mesmo assim a empresa resistiu e se manteve entre as principais empresas de perfumaria, procurando se diferenciar com a fabricação de produtos à base das essências amazônicas.

Verifica-se que, no ano de 1976, a Phebo foi considerada a maior empresa de perfumaria do Brasil e se manteve entre as primeiras (terceira, segunda) nos anos posteriores. Já a Phebo Nordeste oscilou um pouco mais quanto a sua posição, mas esteve sempre entre as dez maiores. Isso demonstra o tamanho e a importância da empresa na estrutura econômica brasileira e principalmente na região Norte do país.

\section{A venda da Phebo para a Procter \& Gamble}

Entre os vários motivos para tomar a decisão de vender uma empresa, Penrose (2006) considera os seguintes:

1) características pessoais dos proprietários e administradores das firmas;

2) os impactos de um sistema específico de tributação;

3) a natureza do mercado de ações e outros fatores particulares.

O primeiro envolve os problemas de administração com as mudanças na sucessão de gerentes ou gerações familiares, os futuros administradores não conseguem manter a empresa gerando lucros. Nas empresas familiares isso acontece quando o patriarca resolve aposentar-se ou, então, esteja inabilitado para continuar trabalhando, cabe aos herdeiros assumir a direção da empresa. Acontece que os desentendimentos entre os familiares levam a crises na sua administração e perda de lucratividade da empresa, podendo chegar até a falir.

O segundo motivo são os impactos da tributação, que envolvem novas decisões dos órgãos fiscalizadores em aumentar determinado imposto que esteja diretamente ligado ao setor no qual a empresa atua. Isso leva a uma perda de receita e a empresa é obrigada a desistir de manter suas atividades e opta pela venda.

E, por fim, o terceiro motivo são os fatores relacionados ao mercado de ações, em que uma queda acentuada no valor das ações da empresa 
faz com que esta se torne desacreditada perante os acionistas e o mercado. Com isso, a empresa, percebendo o declínio nas suas ações, decide negociar os seus ativos.

No entanto, existe também a decisão do agente comprador, no caso, da Procter \& Gamble. A empresa precisava de uma porta para a sua entrada no mercado brasileiro de perfumarias e cosméticos e para isso optou pela compra da Phebo. Segundo Penrose, “em princípio, há dois métodos de expansão abertos a uma firma: ela pode construir um novo estabelecimento e criar novos mercados para si, ou pode adquirir o estabelecimento e os mercados de alguma firma já existente" (Penrose, 2006 , p. 239). Essa última forma é o que se chama de "aquisições e fusões". A Procter \& Gamble optou pelo "método mais barato da expansão", a aquisição de outra empresa.

sempre que a compra de outra firma for considerada o método mais barato de expansão, seguir-se-á que o preço dessa outra firma deverá ser inferior ao investimento necessário (incluindo o custo de oportunidade dos recursos envolvidos) para a firma em expansão construir seu próprio estabelecimento, conseguir formar seu próprio mercado e obter as conexões subjacentes. (Penrose, 2006, p. 241)

Quando se adquire uma empresa, adquirem-se suas estruturas, seus produtos, seus funcionários e também a sua rede de clientes, contendo informações comerciais privilegiadas sobre a carteira de clientes e fornecedores, ou seja, adquirem-se as suas "conexões subjacentes". Por isso, a aquisição é considerada um método mais barato de expansão, porque a adquirente não precisará fazer o caminho da conquista de novos clientes e também da própria confiança dos consumidores.

Segundo Sônia Santiago, ex-vice-presidente do Grupo Phebo desde 1975, a Procter \& Gamble já demonstrava interesse pela compra da Phebo. Mas a decisão de vender só foi ocorrer em 1987, e a aquisição só iria se efetivar em 1988. Penrose (2006) apresentou vários fatores que irão incorrer até a efetivação da venda; existe todo um jogo de negociações até a efetivação da compra.

Por se tratar de uma empresa familiar, a Phebo foi tendo vários problemas com o crescimento da família. No início da década de 1980, começam as disputas por poder dentro da empresa. Mário Santiago, que até então tinha sido o diretor-geral, estava envelhecendo e com problemas 
de saúde. Por esse motivo, em 1978, ele havia deixado a área executiva da empresa, apesar de ter continuado como presidente do conselho de administração do Grupo Phebo. Começavam, assim, as primeiras indicações de que a venda da empresa seria algo inevitável (Santiago, 2009).

Com as disputas por cargos de chefia na empresa, surgiram sinais de decadência no corpo administrativo. Os familiares exigiam trabalhar na gerência, no entanto, não possuíam capacidade para tal cargo (Lima, 2008). Para Schumpeter (1982, p. 56), a "profissão empresário" não é "uma condição duradoura", porque o empresário não transfere a sua técnica para os herdeiros, não forma uma classe social técnica como os agricultores e trabalhadores:

A herança do fruto pecuniário e das qualidades pessoais então tanto pode manter essa posição por mais de uma geração, como tornar mais fácil para os descendentes o empreendimento adicional, mas a função do empresário em si mesma não pode ser herdada, como é suficientemente bem demonstrado pela história das famílias industriais. (Schumpeter, 1982, p. 56)

Além do problema da administração familiar, a empresa tinha grandes dificuldades com os planos econômicos do governo. O congelamento de preços proposto na época do governo Sarney fez com que o valor dos insumos aumentasse e o preço do produto final ficasse estático ${ }^{10}$. Com isso os custos da empresa aumentavam e o lucro diminuía. Cada vez mais foi crescendo a ideia de vender a empresa, e foi aí que, entre 1986 e 1987, Mário Santiago deixa a critério da família a decisão sobre a venda, principalmente a cargo de Sônia Santiago, vice-presidente na época. "As empresas quando chegam a terceira e quarta geração ou elas são vendidas ou elas fecham" (Santiago, 2009). "A experiência ensina, todavia, que os empresários típicos se retiram da arena apenas quando e porque sua força está gasta e não se sentem mais à altura de sua tarefa" (Schumpeter, 1982, p. 64-65).

Logo, no ano de 1988, a empresa é vendida para a Procter \& Gamble Company. O contrato de venda da Perfumarias Phebo S/A para a Procter

10 Um exemplo disso foi o ano de 1976, em que as correções dos preços dos produtos da empresa foram da ordem de $6,8 \%$ em média, enquanto os aumentos dos custos internos, além das matérias-primas, evoluíram em cerca de 18,5\% (Balanço Phebo, 1976). 
\& Gamble possuía cláusulas que diziam que os antigos donos não poderiam criar uma nova empresa do ramo e que a gestão seria transferida em 6 meses. Os antigos diretores foram saindo e entrando novos profissionais.A negociação com a empresa americana demorou 11 meses, começou em 1987 e foi concretizada em 1988 (Santiago, 2009). No dia 19 de abril de 1988, o controle acionário da empresa é passado para a multinacional americana Procter \& Gamble, mas a multinacional só assumiu a administração da Phebo por completo no dia 23 de setembro de 1988.

A Procter procurou investir no parque industrial da empresa, aumentando a tecnologia de operação e também na maior qualificação dos profissionais. Ao todo, a empresa gastou cerca de Cz\$ 803.409 mil, visando aperfeiçoar a produção e também a estrutura administrativa (Balanço Phebo, 1988). Em 1998, a Procter \& Gamble resolve vender a fábrica da Perfumarias Phebo matriz para a Casa Granado, empresa do Rio de Janeiro fundada em 1870, e a marca Phebo para a Sara Lee DE/ Household \& Bodycare do Brasil Ltda. A venda da marca e do sistema operacional (incluindo o prédio da fábrica) consistia em uma estratégia de mercado.A Procter \& Gamble pensava em desenvolver marcas globais, focalizando numa estratégia de marketing que valorizasse seus principais produtos (Pinheiro, 1998).

No ano de 2004, a Sara Lee vendeu a marca para a Casa Granado e, a partir daí, a Casa Granado passa a ter o total controle sobre a empresa. Atualmente, a Phebo continua de posse da Casa Granado, sendo a detentora da marca e responsável pela fabricação dos produtos Phebo. O sabonete Phebo ainda é um sucesso de vendas e permanece sendo muito utilizado no mercado nacional. Apesar de ter mudado o seu processo de fabricação, saindo da essência natural para o sintético, continua tendo um diferencial em relação a outros sabonetes.

\section{Considerações finais}

A estruturação da Phebo se deu na cidade de Belém, inicialmente a empresa investia o seu lucro nos seus próprios ativos, apresentando uma trajetória de crescimento endógena. A partir de 1966, a empresa passa a contar com estímulos gov ernamentais, principalmente através de incentivos fiscais. O primeiro financiamento foi concedido pela SUDAM 
(através de incentivos fiscais e créditos) e possibilitou a expansão da fábrica de Belém. O segundo veio pela SUDENE e tornou possível a instalação de uma nova fábrica na cidade de Feira de Santana, na Bahia. No ano de 1976, a empresa associou-se ao IBRASA, garantindo investimentos para modernizar as suas instalações.

A história da Phebo foi marcada pela liderança de Mário Santiago, que se manteve presente na administração até o momento que pôde (por problemas de saúde foi obrigado a se afastar da empresa); era considerado o mentor e o idealizador do grupo. À frente da empresa, ele conseguiu um vertiginoso crescimento e expansão dos negócios da empresa para outras regiões do país, fazendo da Phebo líder no mercado de perfumaria brasileiro.

Algo interessante a se considerar na análise da trajetória da Phebo foi o fato de a empresa sair de um estado com poucas tradições indústrias e conseguir se instalar em um grande centro industrial brasileiro, no caso, a cidade de São Paulo. O caminho centro-periferia, que normalmente as empresas fazem no momento de expansão, a Phebo o fez inverso, periferia-centro. Esse fato faz da empresa um caso particular, pois ela conseguiu fazer o elo de integração entre o Norte, o Sudeste e o Nordeste do Brasil com as suas três fábricas (Belém, São Paulo e Feira de Santana).

Verificou-se, no trabalho, que o sabonete Phebo Odor de Rosas, a base de pau-rosa, típico da Amazônia, foi o grande impulsionador do crescimento da empresa. No início, a Phebo usou matérias orgânicas para a produção do sabonete. Por volta da década de 1960, a empresa substituiu a essência natural por uma matéria-prima sintética. A empresa não usou a estratégia de investir na pesquisa e na plantação de pau-rosa. Optou por um substituto químico, uma essência sintética para produzir os seus sabonetes.

Outro produto que foi sucesso de venda da empresa foi a colônia Seiva de Alfazema da Phebo. Uma colônia de cheiro suave, desenvolvida por Mário Santiago, que teve grande aceitação no mercado nacional. Sendo utilizada por mães para perfumar as crianças recém-nascidas. Esse produto também marcou a trajetória da empresa, concedeu à Phebo um dos maiores prêmios da propaganda brasileira, com um comercial premiado no Festival de Cannes. A empresa paraense teve considerável êxito no setor de perfumaria brasileiro e sempre procurou se manter 
entre as principais empresas do setor no Brasil, concorrendo com grandes multinacionais, como Gessy Lever, Johnson \& Johnson, L'Oreal, entre outras. Mesmo na década de 1980, período de grandes dificuldades, a empresa se posicionou entre as principais do setor de perfumaria e de higiene e limpeza. A empresa foi vendida em momento de auge, não foi falência, e a sua marca até hoje é uma referência no mercado de sabonetes. Mário Santiago veio a falecer em 1988, no dia em que a empresa seria vendida.

\section{Fontes primárias}

BALANÇO anual. Gazeta Mercantil. São Paulo, ano I, n. 1, set. 1977.

BALANÇO anual. Gazeta Mercantil. São Paulo, ano II, n. 2, set. 1978. BALANÇO anual. Gazeta Mercantil. São Paulo, ano III, n. 3, set. 1979. BALANÇO anual. Gazeta Mercantil. São Paulo, ano III, n. 4, set. 1980. BALANÇO anual. Gazeta Mercantil. São Paulo, ano V, n. 5, set. 1981. BALANÇO anual. Gazeta Mercantil. São Paulo, ano VI, n. 6, set. 1982. BALANÇO anual. Gazeta Mercantil. São Paulo, ano VII, n. 7, set. 1983. BALANÇO anual. Gazeta Mercantil. São Paulo, ano VIII, n. 8, set. 1984. BALANÇO anual. Gazeta Mercantil. São Paulo, ano IX, n. 9, set. 1985. BALANÇO anual. Gazeta Mercantil. São Paulo, ano XI, n. 11, set. 1987. BALANÇO anual. Gazeta Mercantil. São Paulo, ano XII, n. 12, set. 1988. BALANÇO anual. Gazeta Mercantil. São Paulo, ano XIII, n. 13, set. 1989. BALANÇO anual. Gazeta Mercantil. São Paulo, ano XIV, n. 14, set. 1990. BALANÇO Phebo - 1957. A Província do Pará. Belém, 23 abr. 1958. BALANÇO Phebo - 1958. A Província do Pará. Belém, 23 abr. 1959. BALANÇO Phebo - 1959. A Província do Pará. Belém, 27 abr. 1960. BALANÇO Phebo - 1960. A Província do Pará. Belém, 25 abr. 1961. BALANÇO Phebo - 1961. A Província do Pará. Belém, 22 abr. 1962. BALANÇO Phebo - 1962. A Província do Pará. Belém, 26 abr. 1963. BALANÇO Phebo - 1963. A Província do Pará. Belém, 24 abr. 1964. BALANÇO Phebo - 1964. A Província do Pará. Belém, 29 abr. 1965. BALANÇO Phebo - 1965. A Província do Pará. Belém, 24 abr. 1966. BALANÇO Phebo - 1967. A Província do Pará. Belém, 25 abr. 1968. BALANÇO Phebo - 1968. A Província do Pará. Belém, 24 abr. 1969. BALANÇO Phebo - 1969. A Província do Pará. Belém, 10 abr. 1970. BALANÇO Phebo - 1970. A Província do Pará. Belém, 21 abr. 1971. BALANÇO Phebo - 1971. A Província do Pará. Belém, 22 mar. 1972. 
BALANÇO Phebo - 1972. A Província do Pará. Belém, 10 mar. 1973.

BALANÇO Phebo - 1974. A Província do Pará. Belém, 24 abr. 1975.

BALANÇO Phebo - 1976. A Província do Pará. Belém, 24 abr. 1977.

BALANÇO Phebo (1980-1981). Diário Oficial do Estado do Pará. Belém, 12 mar. 1982.

BALANÇO Phebo (1982-1983). Diário Oficial do Estado do Pará. Belém, 23 mar. 1984.

BALANÇO Phebo (1984-1985). Diário Oficial do Estado do Pará. Belém, 25 mar. 1986.

BALANÇO Phebo (1986-1987). Diário Oficial do Estado do Pará. Belém, 19 abr. 1988.

BALANÇO Phebo (1987-1988). Diário Oficial do Estado do Pará. Belém, 29 mar. 1989.

BELÉM está perdendo o cheiro. Diário do Pará. Belém, 26 abr. 1998, Folha Economia, caderno 4.

PARÁ. Álbum do Pará. Belém, 1939.

PARÁ. Diário Oficial do Estado. Belém, 12 nov. 1957.

PARÁ. Junta Comercial do Estado do Pará (JUCEPA). Certidão n. 1. Belém, 23 out. 1969.

PARÁ. Junta Comercial do Estado do Pará (JUCEPA). Certidão n. 1.199/87. Belém, 26 mar. 1987.

REVISTA Exame, Maiores e Melhores, set. 1974.

REVISTA Exame, Maiores e Melhores, set. 1975.

REVISTA Exame, Maiores e Melhores, set. 1976.

REVISTA Exame, Maiores e Melhores, set. 1977.

REVISTA Exame, Maiores e Melhores, set. 1978.

REVISTA Exame, Maiores e Melhores, set. 1979.

REVISTA Exame, Maiores e Melhores, set. 1980.

REVISTA Exame, Maiores e Melhores, set. 1981.

REVISTA Exame, Maiores e Melhores, set. 1982.

REVISTA Exame, Maiores e Melhores, set. 1983.

REVISTA Exame, Maiores e Melhores, set. 1984.

REVISTA Exame, Maiores e Melhores, set. 1985.

REVISTA Exame, Maiores e Melhores, set. 1986.

REVISTA Exame, Maiores e Melhores, set. 1987.

REVISTA Exame, Maiores e Melhores, set. 1988.

REVISTA Exame, Maiores e Melhores, set. 1989.

\section{Entrevistados}

LIMA, Roberto. Belém, 12 nov. 2008, atual gerente da Phebo em Belém.

SANTIAGO, Sônia. Belém, 20 mar. 2009, ex-vice-presidente do Grupo Phebo.

VIDAL, Ramiro. Belém, 14 mar. 2009, ex-diretor industrial da unidade da Phebo em Belém. 


\section{Referências bibliográficas}

A PHEBO quer lavar roupa, dentes e pias. A Província do Pará. Belém, n. 25, 26 mar. 1973.

AS NOSSAS indústrias, Phebo - uma fábrica que honra o Pará não só os perfumes ou os sabonetes, mas também as caixas, os rótulos, as latas são fabricadas aqui. Folha do Norte. Belém, [1954?].

BAER, Werner. The Brazilian economy: growth and development, 2. ed. New York: Praeger, 1983.

BENCHIMOL, Samuel. Estrutura geo-social e econômica da Amazônia. Manaus: Governo do Estado do Amazonas, 1966.

BRASIL. Lei n. 5.174, de 27 de outubro de 1966. Dispõe sobre a concessão de incentivos fiscais em favor da Região Amazônica e dá outras providências. Diário Oficial da União. Brasília, Poder Executivo, 31 out. 1966.

BRASIL. Ministério do Meio Ambiente. Contribuição para a elaboração de um programa de desenvolvimento sustentável para a Amazônia e subsídio para o plano plurianual. Brasília, 2003.

CAMPELLO, Carlos. O estudo sobre empresários e empresas: conceito, relevância e panorama historiográfico. Revista Tema Livre, 2004. Disponível em <http://www. revistatemalivre.com>. Acesso em 1ำ nov. 2008.

COSTA, Francisco de Assis. Grande capital e agricultura na Amazônia: a experiência da Ford no Tapajós. Belém: UFPA/NAEA, 1993.

COSTA, Francisco de Assis. Formação agropecuária da Amazônia: os desafios do desenvolvimento sustentável. Belém: NAEA, 2000.

CURY,Vânia Maria. História da industrialização no século XIX. Rio de Janeiro: Editora UFRJ, 2006.

DALLA COSTA, Armando. História e historiografia empresarial: acesso e utilização de arquivos e fontes. In: DALLA COSTA, Armando; GRAF, Márcia Elisa (org.). Estratégias de desenvolvimento urbano e regional. Curitiba: Juruá, 2004.

DINIZ, Eli. Empresário, Estado e capitalismo no Brasil. Rio de Janeiro: Paz e Terra, 1978.

GÜNTHER, H. Pesquisa qualitativa versus pesquisa quantitativa: está é a questão?. Psicologia: Teoria e Pesquisa. Brasília, v. 22, n. 2, p. 201-210, maio-ago. 2006.

KERSTENETZKY, J. Teoria econômica e história econômica: notas para uma teoria de história econômica empresarial.VII CONGRESSO BRASILEIRO DE HISTÓRIA ECONÔMICA e 8a CONFERÊNCIA INTERNACIONAL DE HISTÓRIA DE EMPRESAS, 2007, Aracaju.

KUHN,Thomas S. A estrutura das revoluções científicas. 9. ed. São Paulo: Perspectiva, 2006.

LAKATOS, E. M.; MARCONI, M. de Andrade. Fundamentos de metodologia científica. São Paulo: Atlas, 1985.

LOBO, Eulália L. História empresarial. In: CARDOSO, Ciro Flamarion;VAENTES, Ronaldo (org.). Domínios da história: ensaios de teoria e metodologia. Rio de Janeiro: Campus, 1997. 
MARCOVITCH, Jacques. Pioneiros E empreendedores: a saga do desenvolvimento no Brasil. São Paulo: Universidade de São Paulo/Saraiva, 2006.

MARTINELlO, Pedro. A batalha da borracha durante a Segunda Guerra Mundial. Rio Branco: UFAC 1988, p. 23-61 (Cadernos UFAC, Série Estudos e Pesquisa, 1).

MCCRAW,Thomas K. (org.). Alfred Chandler: ensaios para uma teoria histórica da grande empresa. Rio de Janeiro: FGV, 1998.

MOURÃO, Leila. Memória da indústria paraense. Belém: Federação das Indústrias do Estado do Pará/SESI/SENAI/IDERPA/IEL, 1989.

PENROSE, Edith. A teoria do crescimento da firma. Campinas: Editora da UNICAMP, 2006.

PHEBO. Memorando da empresa. Belém, 1988.

PINHEIRO, Jecyone. Belém está perdendo o cheiro. Diário do Pará. Belém, 26 abr. 1998, Folha Economia, caderno 4.

SAES, F. A. M. História de empresas e história econômica do Brasil. 4ª CONFERÊNCIA INTERNACIONAL DE HISTÓRIA DE EMPRESAS, 1999, Curitiba, UFPR.

SANTOS, Roberto. Formação econômica da Amazônia. Rio de Janeiro:Vozes, 1980.

SCHUMPETER, J.A. Teoria do desenvolvimento econômico: uma investigação sobre lucros, capital, crédito, juro e ciclo econômico. São Paulo: Abril Cultural, 1982.

YIN, R. K. Estudo de caso: planejamento e métodos. 2. ed. Porto Alegre: Bookman, 2001. 